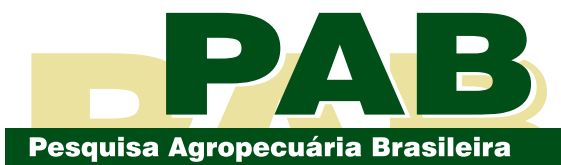

ISSN 1678-3921

Journal homepage: www.embrapa.br/pab

For manuscript submission and journal contents, access: www.scielo.br/pab
Pomology/ Original Article

\section{Phenological, physicochemical, and productive characteristics of 'Vênus' grapevine onto rootstocks}

\begin{abstract}
The objective of this work was to evaluate the phenological characteristics and yield of 'Vênus' grapevine (Vitis labrusca) grafted onto different rootstocks, as well the physicochemical traits of its grapes during the 2013, 2014, and 2015 crop seasons. The evaluated rootstocks were 'IAC 766', 'IAC 572', 'IAC 313' and 'IAC 571-6'. The length of the main phenological stages of the grapevine and its thermal demands were assessed during two growing seasons and expressed as days after pruning and degree-day sum, respectively. Grapevine yield and berry physicochemical characteristics were assessed during three crop seasons. 'Vênus' phenological cycle and thermal demands, as well as the chemical characteristics of its grapes, varied with the climate conditions during the crop seasons. Low temperatures increased the grapevine cycle, and higher rainfall indices caused a decrease in the soluble solids of berries, as well as an increase in their titratable acidity. The 'IAC 766' and 'IAC 571-6' rootstocks promote a greater precocity to 'Venus' grapevines, and 'IAC 572' promotes a higher grapevine yield and better physicochemical characteristics of 'Vênus' grapes.
\end{abstract}

Index terms: Vitis labrusca, degree-days, hybrid grapes, phenological stages, thermal requirement.

\section{Características fenológicas, físico-químicas e produtivas da uva 'Vênus' em porta-enxertos}

Resumo - O objetivo deste trabalho foi avaliar as características fenológicas e a produção da videira 'Vênus' (Vitis labrusca) sobre diferentes porta-enxertos, assim como as características físico-químicas da uva, durante as safras de 2013, 2014 e 2015. Avaliaram-se os porta-enxertos 'IAC 766', 'IAC 572', 'IAC 313' e 'IAC 571-6'. A duração dos principais estádios fenológicos da videira e suas exigências térmicas foram avaliadas em dois ciclos de produção e expressas em dias após a poda e acúmulo de graus-dia, respectivamente. As características produtivas das videiras e as físico-químicas das uvas foram avaliadas durante três ciclos. $\mathrm{O}$ ciclo fenológico e as exigências térmicas da videira 'Vênus', bem como as características químicas de suas uvas, variaram com as condições climáticas durante as safras. As baixas temperaturas proporcionaram aumento do ciclo da videira, e os maiores índices pluviais acarretaram a redução do teor de sólidos solúveis e o aumento da acidez titulável das uvas. Os porta-enxertos 'IAC 766' e 'IAC 571-6' promovem maior precocidade na videira 'Vênus', e 'IAC 572' proporciona maior produção das videiras e melhores características físico-químicas das uvas 'Vênus'.

Termos para indexação: Vitis labrusca, graus-dia, uvas híbridas, estádios fenológicos, necessidade térmica. 


\section{Introduction}

Brazil's grape production in 2016 was about 973 thousand metric tonnes, most of which from Rio Grande do Sul state that is responsible for $42.5 \%$ of the yield. In the same year, state São Paulo state produced around 144 thousand metric tonnes of the fruit, reaching the third position in the national scenario, standing out as the second biggest table grape producer (Levantamento..., 2017). The northwestern of São Paulo state stands out as an important area of grape production in Brazil, more specifically from Vitis vinifera species. However, an expressive increment was verified in nonvinifera table grapes (Vitis labrusca and hybrids) in this region, regarding the period from 2008 to 2015 (IEA, 2017).

'Vênus' is a hybrid red grape cultivar, which shows vigorous vines and produces cylindrical grape clusters that may range from 200 to 500 grams (Tecchio et al., 2006; Danner et al., 2009). 'Vênus' is more robust and has a lower-labor cost compared to Vitis vinifera table grapes, and has a growing period between 90 to 100 days, making it possible to have two annual harvests.

Even though it has been available to Brazilian producers for more than 30 years, 'Vênus' grape is a poorly explored cultivar in Brazil, cultivated only in a few growing areas existing in the country, with few studies on its harversting potential (Danner et al., 2009), particularly in the northwestern São Paulo state (Tecchio et al., 2006). In order to establish new commercial vineyards, with a still unknown variety, it is important to know its phenological, productive, and grape quality characteristics.

The phenological understanding of the harvest is not only relevant for the enlargement of studies for the harvest period, but also it allows of the programming of the plant farming techniques, specially those requiring more labor (Jubileu et al., 2010). Another important tool to assess how long the grapevine developing stages lasts is the characterization of its thermal requirements with the degree-day concept. The required amount of energy for the grapevine to complete its cycle is established by the diference between the average temperature and the base-temperature. If the result is below the plant needs, the crop can not develop adequately (Souza et al., 2009). Studies concerning the relationship between the cycle length and air temperature show that in regions experiencing higher temperatures, the farming cycle of grapevine is shorter because of its rapid growth (Neis et al., 2010).

Grape quality and growing characteristics can also be influenced by multiple factors; among which are the climate conditions in each region, rootstock handling, and graft variety used. The interaction between scion and rootstock can make a difference on the vegetative growth, production, and quality of grapevine clusters (Mota et al., 2009; Tsegay et al., 2014). Therefore, the rootstock reference cannot be based solely on the grapevine yield, but also on the qualitative characteristics of grape (Dias et al., 2012; Ibacache et al., 2016).

The objective of this work was to evaluate the phenological characteristics and yield of 'Vênus' grapevine grafted onto different rootstocks, as well the physicochemical traits of its grapes during the 2013, 2014, and 2015 crop seasons.

\section{Materials and Methods}

The experiment was carried out in an experimental vineyard, located in the municipality of Votuporanga $\left(20^{\circ} 15^{\prime} \mathrm{S}, 50^{\circ} 30^{\prime} \mathrm{W}\right.$, at $483 \mathrm{~m}$ altitude) in the state of São Paulo, Brazil. According to Köppen-Geiger's classification, the local climate type is Aw, with $24.3^{\circ} \mathrm{C}$ average temperature, and 1,449 $\mathrm{mm}$ average annual rainfall, with a tendency for concentrated rainfall during summer months (Cepagri, 2017). The climatic data during the studied cycles are shown in Figure 1. The soil of the area was classified as Argissolo Vermelho-Amarelo (Ultisol) according to Santos et al. (2013).

The experimental design was a completely randomized block, in a two-factor $4 \times 3$ factorial arrangement, with 10 replicates, and four vines per plot. The factors consisted of four rootstocks 'IAC 766', 'IAC 572', 'IAC 313' e 'IAC 571-6' -, and three growing seasons, 2013, 2014, and 2015. The phenological characteristics and thermal demands of the vines were assessed in the 2014 and 2015 seasons. The grapevine yield characteristics, and the physicochemical characteristics of the berries were assessed in the 2013, 2014, and 2015 seasons.

The vines were trained on a pergola system, spaced at $2.0 \times 2.0 \mathrm{~m}$ apart $(2,500$ vines per hectare). Plant irrigation was performed with a microaspersion system according to crop demands. Regular crop pruning was performed on August 4, 2013, July 25, 
2014, and July 04, 2015. Over all seasons, the vines were cane pruned maintaining six to eight nodes in every of the 12 to 14 canes maintained per vine. Subsequently, 5\% hydrogen cyanamide was applied to the last two buds to induce and standardize the sprouting. Thereafter, a shoot was selected with cluster primordia per cane, standardizing a load from 12 to 14 buds per vine $(30,000$ to 35,000 buds per hectare). Other cultural practices regarding fertilization, weed control, and pest and disease management were performed as standard regional cultivation practices.

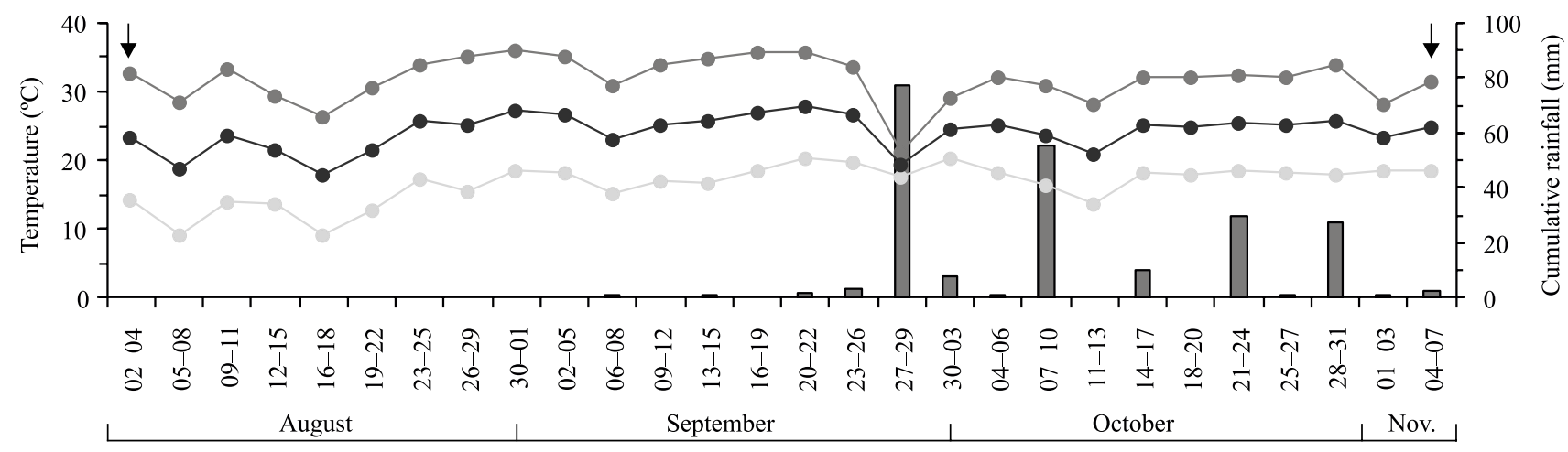

Productive period (2013)
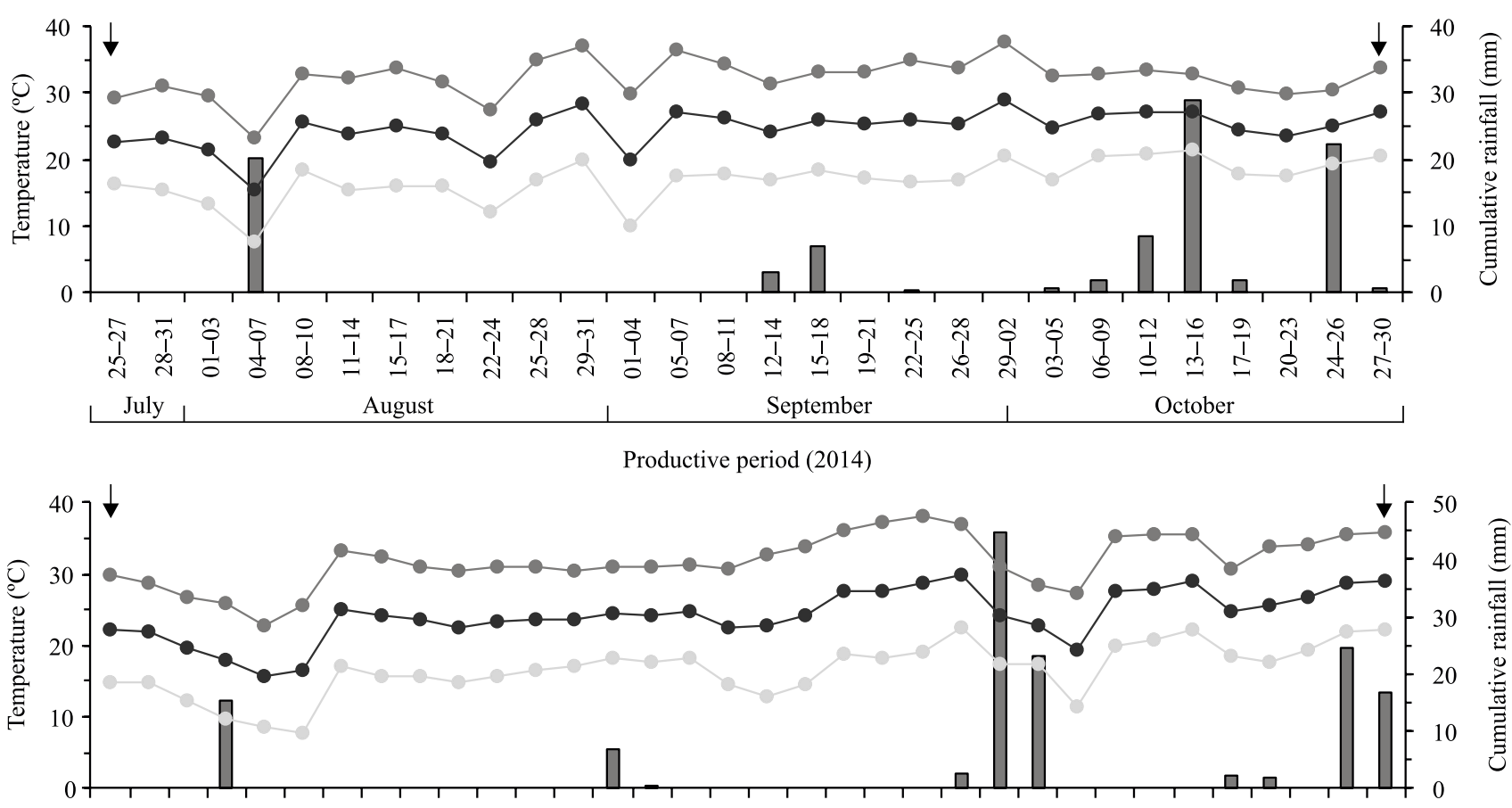

¿

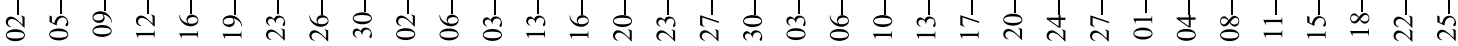
July August September October

Productive period (2015)

$\multimap$ Cumulative rainfall $\multimap$ Maximum temperature $\multimap$ Minimum temperature $\multimap$ Average temperature

Figure 1. Climate data in the municipality of Votuporanga, in the state of São Paulo, Brazil, during the 'Vênus' grapevine (Vitis labrusca) growing seasons of 2013, 2014, and 2015. Pruning and harvesting time are marked by arrows. 
The phenological stages were assessed by criteria proposed by Coombe (1995), and the evaluations were carried out twice a week, until plants were fully bloomed; after this stage, evaluations were performed weekly. The phenological stages from pruning to budburst, full-bloom ( $50 \%$ caps off), setting, veraison (when berries begin to color), and harvest were determined by visual observation. Lengths of phenological stages were expressed as days after pruning (DAP).

For the thermal demands, degree-day (DD) summation was calculated from pruning to harvest, according to the following equation, proposed by Winkler (1965): $\mathrm{DD}=\Sigma$ (average temperature $-10^{\circ} \mathrm{C}$ ) $\times$ days after pruning.

To estimate the productivity, the average yield per vine $(\mathrm{kg})$ from each plot was multiplied by the number of plants per hectare, and the result was expressed in megagrams per hectare.

For physical characteristics, 10 clusters were sampled per experimental plot, to determine the number of berries per cluster, cluster mass (g), rachis mass (g), and cluster length and width (both in $\mathrm{cm}$ ). Ten berries were collected from each cluster, with a total of 100 berries per experimental plot, in order to determine berry mass (g), length $(\mathrm{mm})$, and width ( $\mathrm{mm})$.

Chemical evaluations of must were performed according to must $\mathrm{pH}$, soluble solids (SS), titratable acidity (TA) and SS/TA ratio values. Must $\mathrm{pH}$ was determined directly by a potentiometer (Tecnal, Piracicaba, SP, Brazil). SS ( ${ }^{\circ}$ Brix) were determined using a digital refractometer r2i300 (Reichert, Buffalo, NY, EUA). TA was determined through the must titration with $0.1 \mathrm{~N} \mathrm{NaOH}$ solution, adopting the end-point at $\mathrm{pH}=8.2$, and the result was expressed as tartaric acid percentage (OIV, 2015).

The data were subjected to analysis of variance and compared by Tukey's test, at $5 \%$ probability, by the Sisvar statistical program. Pearson's correlation analyses were performed to investigate the relationship between yield, and physical and chemical characteristics.

\section{Results and Discussion}

There was a significant interaction between the rootstocks and the growing seasons for all phenological stages and degree-day summation of 'Vênus' grapevine (Table 1).

In 2015, the rootstocks did not affect the budburst, full-bloom, setting, veraison, and harvest phenological stages. However, in general, in 2014, 'IAC 766' and 'IAC 571-6' rootstocks promoted precocity in 'Vênus' grapevines. This characteristic was observed since the budburst stage, which occurred on average at 15.7 DAP, when vines were grafted onto 'IAC 313' and 'IAC 572'. However, the same phenological stage occurred at 12.9 DAP with 'IAC 766' and 'IAC 571-6'.

Vines grafted onto 'IAC 313' and 'IAC 572' took a larger number of days after pruning, with few variations, to reach all phenological stages. The harvest stage of vines grafted onto 'IAC 313' and 'IAC 572 ' was performed at $89.7 \mathrm{DAP}$, and for grapevines grafted onto 'IAC 766' and 'IAC 571-6', harvest was carried out at 86.5 DAP (Table 1). Similar results were found by Tecchio et al. (2011) for 'Niagara Rosada', grafted on the same rootstocks assessed in the present study; these authors verified that the required time for 'Niagara Rosada' to reach budburst, full-bloom,

Table 1. Phenological stages calculated as days after pruning, and degree-day sum between pruning and harvesting of 'Venus' grapevines (Vitis labrusca) grown onto different rootstocks during two growing seasons ${ }^{(1)}$.

\begin{tabular}{|c|c|c|c|c|c|c|c|c|c|c|c|c|}
\hline \multirow{2}{*}{ Rootstock } & \multicolumn{2}{|c|}{ Budburst } & \multicolumn{2}{|c|}{ Full-bloom } & \multicolumn{2}{|c|}{ Setting } & \multicolumn{2}{|c|}{ Veraison } & \multicolumn{2}{|c|}{ Harvest } & \multicolumn{2}{|c|}{ Degree-day sum } \\
\hline & 2014 & 2015 & 2014 & 2015 & 2014 & 2015 & 2014 & 2015 & 2014 & 2015 & 2014 & 2015 \\
\hline IAC 313 & $15.7 \mathrm{aA}$ & $14.1 \mathrm{aB}$ & $35.5 \mathrm{aB}$ & $38.7 \mathrm{aA}$ & $39.7 \mathrm{abB}$ & $44.4 \mathrm{aA}$ & $73.3 \mathrm{aA}$ & $74.4 \mathrm{aA}$ & $90.0 \mathrm{aB}$ & $93.1 \mathrm{aA}$ & $1,646 \mathrm{aB}$ & $1,828 \mathrm{aA}$ \\
\hline IAC 572 & $15.6 \mathrm{aA}$ & $14.1 \mathrm{aB}$ & $35.5 \mathrm{aB}$ & $38.4 \mathrm{a}$ & $40.6 \mathrm{aB}$ & $43.6 \mathrm{aA}$ & $73.9 \mathrm{aA}$ & $74.8 \mathrm{aA}$ & 89.3abB & $92.6 \mathrm{aA}$ & $1,634 \mathrm{abB}$ & $1,820 \mathrm{aA}$ \\
\hline IAC 571-6 & $12.1 \mathrm{bB}$ & $14.1 \mathrm{aA}$ & $32.7 \mathrm{bB}$ & $38.9 \mathrm{aA}$ & $38.0 \mathrm{bB}$ & $44.4 \mathrm{aA}$ & $69.6 \mathrm{bB}$ & $75.5 \mathrm{aA}$ & $86.2 \mathrm{cB}$ & $92.8 \mathrm{aA}$ & $1,585 \mathrm{cB}$ & $1,823 \mathrm{aA}$ \\
\hline IAC 766 & $13.7 \mathrm{bA}$ & $14.1 \mathrm{aA}$ & $34.0 \mathrm{abB}$ & $38.5 \mathrm{aA}$ & $38.5 \mathrm{abB}$ & $44.1 \mathrm{aA}$ & $73.2 \mathrm{aA}$ & $75.1 \mathrm{aA}$ & $86.8 \mathrm{bcB}$ & $93.4 \mathrm{aA}$ & $1,594 \mathrm{bcB}$ & $1,834 \mathrm{aA}$ \\
\hline CV (\%) & \multicolumn{2}{|c|}{10.33} & \multicolumn{2}{|c|}{4.87} & \multicolumn{2}{|c|}{4.48} & \multicolumn{2}{|c|}{3.44} & \multicolumn{2}{|c|}{2.58} & \multicolumn{2}{|c|}{8.13} \\
\hline
\end{tabular}

${ }^{(1)}$ Means followed by equal letters, lowercase in the columns and uppercase in the lines, do not differ by Tukey's test, at $5 \%$ probability. 
setting, veraison, and harvest stages was longer for vines grafted onto 'IAC 572' and 'IAC 571-6' than on 'IAC 766' and 'IAC 313'. The rootstock influence on the growing season might be related to its vigor, nutrients, and water uptake for the grapevine photosynthesis, which helps with the absorption of necessary stocks for its nutrition (Barros et al., 2015).

Compared to 2014, in the 2015 growing season, for all rootstocks, the grapevines demanded a larger number of DAP to reach the harvest stage, which happened, on average, at 93 DAP. Certainly, the difference between growing seasons is related to the climate conditions from each season. In 2015, the lowest-average air temperature $\left(24.18^{\circ} \mathrm{C}\right)$ was recorded in the period between pruning and harvest, comparing to the 2014 cycle $\left(24.61^{\circ} \mathrm{C}\right)$ (Figure 1).

Similar results to those obtained in the phenological stages were also observed regarding vine degreeday summation (Table 1). There was no significant difference among rootstocks in 2015 (1,826.1 degreeday sum). In contrast, in 2014, the largest degree-day summation was observed in grapevines grafted onto 'IAC 313' and 'IAC 572', with an average of 1,639.8 degree-day sum. For grapevines grafted onto 'IAC 766 ' and 'IAC 571-6', the average was of 1,589.7 degree-day sum. Regardless the rootstock, the thermal demands of grapevines in 2015 were higher than those observed in 2014, requiring a further 211.4 degree-day sum. This result relates to the minimum temperatures recorded in both growing seasons, which were lower in 2015.

The degree-day concept assumes the existence of a basis temperature, considered $10^{\circ} \mathrm{C}$ by other authors (Neis et al., 2010; Borges et al., 2014; Barros et al., 2015), below which vegetal growing can be disregarded (Pezzopane et al., 2008). During the 2014 cycle, these minimum temperatures were below the basis temperature for three days. However, in 2015 the minimum temperatures were below $10^{\circ} \mathrm{C}$ for 10 days (Figure 1). These low temperatures were recorded during the budburst stage of grapevines precisely, a phenological phase narrowly related to the farming region thermal availability (Neis et al., 2010). In addition to the influence on the degree-day summation, these conditions certainly influenced the time length which the phenological stages of grapevines lasted.

There was no significant interaction between the rootstocks and the growing seasons for yield attributes of all grapevines (Table 2), and physical characteristics of clusters and berries (Table 3). Thus, both factors (rootstocks and growing seasons) were analyzed separately.

As to the isolated effect of rootstocks on yield characteristics, 'IAC 572' and 'IAC 766' provided a similar number of clusters to one another, with an average of 32 clusters per vine. The number of clusters per vine was one of the variables that most contributed to the cultivar yield, which was verified by the highly significant correlation between those characteristics. Nevertheless, the highest yield and productivity were obtained from 'Vênus' grafted onto 'IAC 572', with an average of $6.11 \mathrm{~kg}$ per vine and $15.29 \mathrm{Mg} \mathrm{ha}^{-1}$, respectively (Table 2). Vigor conferred by rootstocks to scions is one of the factors that can affect grapevine yield (Bascunán-Godoy et al., 2017). However it is not clear which are the biochemical or physiological effects that occur in that interaction.

Regarding the effect of the growing seasons on yield characteristics, in 2015 the 'Vênus' grapevines showed a higher number of clusters than in 2014 and 2013 (Table 2). However, there was no significant difference between the growing seasons of 2014 and 2015 for the vine yield and productivity. For all growing seasons, the number of clusters per vine and yield of 'Vênus' grapevine were lower than the values observed for the same cultivar grown in the Submédio do Vale do São Francisco, in the Northeaster of Brazil, where

Table 2. Yield characteristics of 'Venus' grapevines (Vitis labrusca) grown onto different rootstocks during three growing seasons ${ }^{(1)}$.

\begin{tabular}{lccc}
\hline Rootstock & $\begin{array}{c}\text { Yield } \\
(\text { kg per vine })\end{array}$ & $\begin{array}{c}\text { Productivity } \\
\left(\mathrm{Mg} \mathrm{ha}^{-1}\right)\end{array}$ & $\begin{array}{c}\text { No. of clusters } \\
\text { per vine }\end{array}$ \\
\hline IAC 313 & $2.48 \mathrm{c}$ & $6.19 \mathrm{c}$ & $20.14 \mathrm{c}$ \\
IAC 572 & $6.11 \mathrm{a}$ & $15.29 \mathrm{a}$ & $33.09 \mathrm{a}$ \\
IAC 571-6 & $3.63 \mathrm{bc}$ & $9.08 \mathrm{bc}$ & $24.90 \mathrm{bc}$ \\
IAC 766 & $3.82 \mathrm{~b}$ & $9.55 \mathrm{~b}$ & $30.59 \mathrm{ab}$ \\
\hline Growing season & & & \\
2013 & $3.08 \mathrm{~b}$ & $7.70 \mathrm{~b}$ & $16,76 \mathrm{c}$ \\
2014 & $4.26 \mathrm{a}$ & $10.65 \mathrm{a}$ & $28.85 \mathrm{~b}$ \\
2015 & $4.70 \mathrm{a}$ & $11.74 \mathrm{a}$ & $35.98 \mathrm{a}$ \\
\hline CV (\%) & 42.64 & 42.64 & 35.87 \\
\hline
\end{tabular}

${ }^{(1)}$ Means followed by equal letters, in the columns, do not differ by Tukey's test, at $5 \%$ probability. 
grapevines grafted onto 'IAC 572' showed 61 clusters per plant, with $9.45 \mathrm{~kg}$ per plant, over five growing seasons (Leão \& Pereira, 2001). The higher number of clusters per plant might be related to a bigger spacing between vines, as the aforementioned authors used $4.0 \times 2.0 \mathrm{~m}$ spacing, while in the present study spacing was $2.0 \times 2.0 \mathrm{~m}$. The grapevine productivity is an important characteristic concerning hybrid varieties in which the high productivity is an essential requirement to its farming viability (Hernandes et al., 2010).

'IAC 572' rootstock provided the highest-cluster mass (312.9 g) to 'Vênus' grapevine (Table 3); this result is directly correlated to the highest values of cluster length $(17.06 \mathrm{~cm})$, cluster width $(10.66 \mathrm{~cm})$, number of berries per cluster (90.29), and rachis mass (5.02). In contrast, smaller clusters, with a lower mass and a lower number of berries were found on the grapevines grafted onto 'IAC 313' and 'IAC 766', with $186 \mathrm{~g}, 13.76 \mathrm{~cm}$, and 54 berries per cluster. Both 'IAC 572 ' and 'IAC 313 ' are high-vigor rootstocks, while 'IAC 766' is less vigorous. Thus, no correlation was noticed between rootstock vigor and yield, or cluster physical characteristics of the clusters.

The cluster mass of 'Vênus' from all assessed rootstocks, in the present work, was heavier than that observed for the same variety grafted onto ' $420-\mathrm{A}^{\prime}$ rootstock in the municipality of Ponta Grossa, in the state of Paraná, Brazil, where cluster mass was $145 \mathrm{~g}$ (Sozim et al., 2007). However, Danner et al. (2009) obtained 316 g cluster mass for 'Vênus' onto 'Paulsen
1103 ', comparable only to 'IAC 572' of the present work. With these results, is possible to infer that the scionrootstock interaction seems to be more responsive than the isolated effect of the rootstock on the canopy.

Cluster physical attributes significantly affected yield and productivity of the vines. 'IAC 572' and 'IAC 766' rootstocks provided bigger and heavier berries, with an average of $3.45 \mathrm{~g}, 18.95 \mathrm{~mm}$ length, and $17.55 \mathrm{~mm}$ width (Table 3). However, the physical characteristics of berries did not affect grapevine yield.

No effect of growing seasons was detected on cluster mass and length (Table 3). Nevertheless, a larger cluster width and a higher number and size of berries were detected in 2013. A study carried out with 'Vênus' in Jales, SP, Brazil, also showed indications of the effect of each productive year concerning length and the number of clusters, and mass and size of berries (Tecchio et al., 2006), for which the authors observed, in the second assessed year, higher figures of this characteristics in contrast to the first year.

As to chemical characteristics of 'Vênus' must, there was no significant interaction between rootstocks and growing seasons for $\mathrm{pH}$ and soluble solids content (Table 4). However, interaction between those factors was verified for titratable acid and ratio (Table 5).

The highest $\mathrm{pH}$ was found in grapes from the vines grafted onto 'IAC 313' (3.28) and 'IAC 572' (3.23). Vines grafted onto 'IAC 313 ' produced also grapes with a higher content of soluble solid (15.65 ${ }^{\circ}$ Brix), which did not differ significantly from that of 'IAC

Table 3. Physical characteristics of clusters and berries of 'Venus' grapevines (Vitis labrusca) grown onto different rootstocks during three growing seasons ${ }^{(1)}$.

\begin{tabular}{lcccccccc}
\hline Rootstock & CM $(\mathrm{g})$ & CL $(\mathrm{cm})$ & CW $(\mathrm{cm})$ & BPC & RM $(\mathrm{g})$ & BM $(\mathrm{g})$ & BL $(\mathrm{mm})$ & $\mathrm{BW}(\mathrm{mm})$ \\
\hline IAC 313 & $171.5 \mathrm{c}$ & $13.45 \mathrm{c}$ & $8.66 \mathrm{c}$ & $52.36 \mathrm{c}$ & $2.89 \mathrm{c}$ & $3.19 \mathrm{~b}$ & $18.50 \mathrm{~b}$ & $17.04 \mathrm{~b}$ \\
IAC 572 & $312.9 \mathrm{a}$ & $17.06 \mathrm{a}$ & $10.66 \mathrm{a}$ & $90.29 \mathrm{a}$ & $5.02 \mathrm{a}$ & $3.42 \mathrm{a}$ & $18.80 \mathrm{ab}$ & $17.55 \mathrm{a}$ \\
IAC 571-6 & $251.1 \mathrm{~b}$ & $15.50 \mathrm{~b}$ & $9.34 \mathrm{~b}$ & $76.98 \mathrm{~b}$ & $4.09 \mathrm{~b}$ & $3.20 \mathrm{~b}$ & $18.53 \mathrm{~b}$ & $17.26 \mathrm{ab}$ \\
IAC 766 & $200.6 \mathrm{c}$ & $14.07 \mathrm{c}$ & $9.33 \mathrm{~b}$ & $56.29 \mathrm{c}$ & $3.11 \mathrm{c}$ & $3.48 \mathrm{a}$ & $19.09 \mathrm{a}$ & $17.55 \mathrm{a}$ \\
\hline Growing season & & & & & & & \\
2013 & $241.5 \mathrm{a}$ & $14.76 \mathrm{a}$ & $10.28 \mathrm{a}$ & $73.56 \mathrm{a}$ & $4.38 \mathrm{a}$ & $3.22 \mathrm{~b}$ & $19.30 \mathrm{a}$ & $17.77 \mathrm{a}$ \\
2014 & $230.3 \mathrm{a}$ & $15.15 \mathrm{a}$ & $9.11 \mathrm{~b}$ & $66.71 \mathrm{~b}$ & $3.47 \mathrm{~b}$ & $3.38 \mathrm{a}$ & $18.44 \mathrm{~b}$ & $17.14 \mathrm{~b}$ \\
2015 & $230.2 \mathrm{a}$ & $15.15 \mathrm{a}$ & $9.10 \mathrm{~b}$ & $66.67 \mathrm{~b}$ & $3.47 \mathrm{~b}$ & $3.38 \mathrm{a}$ & $18.44 \mathrm{~b}$ & $17.14 \mathrm{~b}$ \\
\hline CV (\%) & 22.95 & 13.47 & 7.79 & 20.88 & 25.04 & 7.15 & 3.02 & 2.72 \\
\hline
\end{tabular}

(1)Means followed by equal letters, in the columns, do not differ by Tukey's test, at 5\% probability. CM, cluster mass; CL, cluster length; CW, cluster width; BPC, number of berries per cluster; RM, rachis mass; BM, berry mass; BL, berry length; BW, berry width. 
$7666^{\prime}\left(15.22^{\circ}\right.$ Brix). The effect of rootstocks on chemical composition of grapes might be related to factors such as vigor, nutrients, and water intake capacity, resistance to diseases, and scion-rootstock interaction. This way, this effect can influence directly the primary and secondary metabolic and, consequently, the grape quality (Dias et al., 2012; Lee \& Steenwerth, 2013; Tecchio et al., 2014). However, as observed for the yield characteristics, no correlation was observed between the vigor of rootstocks and the chemical characteristics of grapes.

Regarding the growing seasons, the lowest values of $\mathrm{pH}$ and soluble solids were found in grapes produced

Table 4. $\mathrm{pH}$ and content of soluble solids of 'Venus' grapes (Vitis labrusca) grown onto different rootstocks during three growing seasons ${ }^{(1)}$.

\begin{tabular}{lcc}
\hline Rootstock & $\mathrm{pH}$ & Soluble solids $\left({ }^{\circ}\right.$ Brix $)$ \\
\hline IAC 313 & $3.28 \mathrm{a}$ & $15.65 \mathrm{a}$ \\
IAC 572 & $3.23 \mathrm{ab}$ & $14.98 \mathrm{~b}$ \\
IAC 571-6 & $3.21 \mathrm{~b}$ & $14.82 \mathrm{~b}$ \\
IAC 766 & $3.21 \mathrm{~b}$ & $15.22 \mathrm{ab}$ \\
\hline Growing season & & \\
\hline 2013 & $2.86 \mathrm{c}$ & $14.35 \mathrm{~b}$ \\
2014 & $3.45 \mathrm{a}$ & $15.56 \mathrm{a}$ \\
2015 & $3.38 \mathrm{~b}$ & $15.59 \mathrm{a}$ \\
\hline CV (\%) & 2.81 & 4.89 \\
\hline
\end{tabular}

(1)Means followed by equal letters, in the columns, do not differ by Tukey's test, at $5 \%$ probability. in 2013, with 2.86 and $14.35^{\circ}$ Brix, respectively. No difference between the growing seasons of 2014 and 2015 was detected concerning the content of soluble solids. The lowest $\mathrm{pH}$ and content of soluble solids in grapes produced in 2013 is related to the higher-rainfall index $(126 \mathrm{~mm})$ recorded in that year (Figure 1), which occurred from veraison to harvest stages, while in 2014 and 2015, the cumulative rainfall was of 64 and $65 \mathrm{~mm}$, respectively.

In 2013, grapes showed a titratable acid content higher than those berries harvested in 2014 and 2015 (Table 5). The high-titratable acidity and the lowsoluble solid contents of the grapes harvested in 2013 directly affected the maturation index (SS/TA ratio), which was higher in the growing seasons of 2014 and 2015. The influence on the soluble solid contents, as well as the climatic variation between the growing seasons also influenced titratable acid in the grapes, in which the highest rainfall index in 2013 may have favored higher-acid content rates.

There was no significant rootstock effect on titratable acid of grapes yielded in 2014 and 2015. However, in 2013, 'IAC 571-6' and 'IAC 766' rootstocks provided the lowest values of acid content to 'Vênus' grapes, which showed a higher SS/TA ratio. According to Rizzon \& Mielle (2002), the increase of sugar contents in berries does not always equally correspond to the decrease of acid content. By this reason, this ratio should used with caution, mainly by growers who normally use the maturation index as a characteristic to measure the grape quality.

Table 5. Titratable acidity and maturation index of 'Venus' grapes (Vitis labrusca) grown onto different rootstocks during 2013, 2014, 2015 growing seasons ${ }^{(1)}$.

\begin{tabular}{|c|c|c|c|c|c|c|}
\hline \multirow[t]{2}{*}{ Rootstock } & \multicolumn{3}{|c|}{ Titratable acidity (\% tartaric acid) } & \multicolumn{3}{|c|}{ Maturation index (ratio) } \\
\hline & 2013 & 2014 & 2015 & 2013 & 2014 & 2015 \\
\hline IAC 313 & $1.28 \mathrm{aA}$ & $0.58 \mathrm{aB}$ & $0.56 \mathrm{aB}$ & $11.45 \mathrm{bB}$ & $27.94 \mathrm{aA}$ & $29.54 \mathrm{aA}$ \\
\hline IAC 572 & $1.08 \mathrm{bA}$ & $0.61 \mathrm{aB}$ & $0.62 \mathrm{aB}$ & 13.51abB & $25.61 \mathrm{aA}$ & $24.73 \mathrm{bA}$ \\
\hline IAC $571-6$ & $0.88 \mathrm{cA}$ & $0.62 \mathrm{aB}$ & $0.61 \mathrm{aB}$ & $16.68 \mathrm{aB}$ & $25.07 \mathrm{aA}$ & $24.84 \mathrm{bA}$ \\
\hline IAC 766 & $0.88 \mathrm{cA}$ & $0.60 \mathrm{aB}$ & $0.59 \mathrm{aB}$ & $16.54 \mathrm{aB}$ & $25.92 \mathrm{aA}$ & $27.06 \mathrm{abA}$ \\
\hline $\mathrm{CV}(\%)$ & \multicolumn{3}{|c|}{11.91} & \multicolumn{3}{|c|}{12.86} \\
\hline
\end{tabular}

${ }^{(1)}$ Means followed by equal letters, lowercase in the columns and uppercase in the lines, do not differ by Tukey's test, at 5\% probability. 


\section{Conclusions}

1. The phenological cycle and thermal demands of 'Venus' grapevines (Vitis labrusca), as well as grape chemical characteristics of this cultivar vary with the climate conditions during the growing seasons.

2. Rootstocks 'IAC 766' and 'IAC 571-6' promote a greater precocity to 'Venus' grapevines.

3. 'IAC 572' rootstock promotes the highest yield of vines and the best physicochemical characteristics of 'Vênus' grapes.

\section{Acknowledgments}

To Conselho Nacional de Desenvolvimento Científico e Tecnológico (CNPQ, grant numbers 305724/2018-5 and 140211/2015-2); to Coordenação de Aperfeiçoamento de Pessoal de Nível Superior (Capes); and to Fundação de Amparo à Pesquisa do Estado de São Paulo (Fapesp, grant number 2013/08913-5), for financial support.

\section{References}

BARROS, L.B.; MARGOTI, G.; FOWLER, J.G.; MIO, L.L.M. DE; BIASI, L.A. Thermal requirement and phenology of different cultivars of Vitis labrusca on different rootstocks. Semina: Ciências Agrárias, v.36, p.2433-2442, 2015. DOI: https://doi. org/10.5433/1679-0359.2015v36n4p2433.

BASCUNÁN-GODOY, L.; FRANCK, N.; ZAMORANO, D.; SANHUEZA, C.; CARVAJAL, D.E.; IBACACHE, A. Rootstock effect on irrigated grapevine yield under arid climate conditions are explained by changes in traits related to light absorption of the scion. Scientia Horticulturae, v.218, p.284-292, 2017. DOI: https://doi.org/10.1016/j.scienta.2017.02.034.

BORGES, R. DE de S.; ROBERTO, S.R.; YAMASHITA, F.; ASSIS, A.M. DEde; YAMAMOTO, L.Y. Ciclo de produção e demanda térmica de clones da videira 'Concord' sobre diferentes porta-enxertos. Revista Brasileira de Fruticultura, v.36, p.884891, 2014. DOI: https://doi.org/10.1590/0100-2945-384/13.

CEPAGRI. Centro de Pesquisas Meteorológicas e Climáticas Aplicadas à Agricultura. Clima dos municípios paulistas. Available at: <http://www.cpa.unicamp.br/outras-informacoes/ clima-dos-municipios-paulistas.html>. Acessed on: Jan. 182017.

COOMBE, B.G. Growth Stages of the Grapevine: Adoption of a system for identifying grapevine growth stages. Australian Journal of Grape and Wine Research, v.1, p.104-110, 1995. DOI: https://doi.org/10.1111/j.1755-0238.1995.tb00086.x.

DANNER, M.A.; CITADIN, I.; SASSO, S.A.Z.; ZARTH, N.A.; MAZARO, S.M. Fontes de cálcio aplicadas no solo e sua relação com a qualidade da uva 'Vênus'. Revista Brasileira de
Fruticultura, v.31, p.881-889, 2009. DOI: https://doi.org/10.1590/ S0100-29452009000300035.

DIAS, F.A.N.; MOTA, R.V.; FÁVERO, A.C.; PURGATTO, E.; SHIGA, T.M.; SOUZA, C.R.; PIMENTEL, R.M.A.; REGINA, M.A. Videira 'Syrah' sobre diferentes porta-enxertos em ciclo de inverno no sul de Minas Gerais. Pesquisa Agropecuaria Brasileira, v.47, p.208-215, 2012. DOI: https://doi.org/10.1590/ S0100-204X2012000200009.

HERNANDES, J.L.; PEDRO JÚNIOR, M.J.; SANTOS, A.O.; TECCHIO, M.A. Fenologia e produção de cultivares americanas e híbridas de uvas para vinho, em Jundiaí-SP. Revista Brasileira de Fruticultura, v.32, p.135-142, 2010. DOI: https://oi.org/10.1590/ S0100-29452010005000040.

IBACACHE, A.; ALBORNOZ, F.; ZURITA-SILVA, A. Yield responses in Flame seedless, Thompson seedless and Red Globe table grape cultivars are differentially modified by rootstocks under semi arid conditions. Scientia Horticulturae, v.204, p.2532, 2016. DOI: https://doi.org/10.1016/j.scienta.2016.03.040.

IEA. Instituto de Economia Agrícola. Estatísticas da produção paulista. Available at: <http://www.iea.sp.gov.br/out/index.php>. Acessed on: Jan. 292017.

JUBILEU, B. da S.; SATO, A.J.; ROBERTO, S.R. Caracterização fenológica e produtiva das videiras 'Cabernet Sauvignon' e 'Alicante' (Vitis vinifera L.) produzidas fora de época, no norte do Paraná. Revista Brasileira de Fruticultura, v.32, p.451-462, 2010. DOI: https://doi.org/10.1590/S0100-29452010005000051.

LEÃO, P.C.S.; PEREIRA, F.M. Avaliação de seis variedades de uvas sem sementes no Submédio São Francisco. Pesquisa Agropecuaria Brasileira, v.36, p.607-613, 2001. DOI: https://doi. org/10.1590/S0100-204X2001000400003.

LEE, J.; STEENWERTH, K.L. 'Cabernet Sauvignon' grape anthocyanin increased by soil conservation practices. Scientia Horticulturae, v.159, p.128-133, 2013. DOI: https://doi. org/10.1016/j.scienta.2013.05.025.

LEVANTAMENTO SISTEMÁTICO DA PRODUÇÃO AGRÍCOLA: pesquisa mensal de previsão e acompanhamento das safras agrícolas no ano civil. Rio de Janeiro: IBGE, v.30, p.186, 2017.

MOTA, R.V.; SOUZA, C.R.; FAVERO, A.C.; SILVA, C.P.C.; CARMO, E.L.; FONSECA, A.R.; REGINA, M.A. Produtividade e composição físico-química de bagas de cultivares de uva em distintos porta-enxertos. Pesquisa Agropecuaria Brasileira, v.44, p.576-582, 2009. DOI: https://doi.org/10.1590/S0100204X2009000600005.

NEIS, S.; SANTOS, S.C.; ASSIS, K.C. de; MARIANO, Z. de F. Caracterização fenológica e requerimento térmico para a videira niagara rosada em diferentes épocas de poda no sudoeste Goiano. Revista Brasileira de Fruticultura, v.32, p.931-937, 2010. DOI: https://doi.org/10.1590/S0100-29452010005000081.

OIV. Organisation Internationale de la Vigne et du Vin. Recueil des Méthods Internationales d'Analyse des Vins et des Moûts. Available at: <http://www.oiv.int/en/normes-et-documentstechniques/methodes-danalyse/>. Acessed on: Dec. 132015. 
PEZZOPANE, J.R.M.; PEDRO JÚNIOR, M.J.; CAMARGO, M.B.P. de; FAZUOLI, L.C. Exigência térmica do café arábica cv. Mundo Novo no subperíodo florescimento-colheita. Ciência e Agrotecnologia, v.32, p.1781-1786, 2008. DOI: https://doi. org/10.1590/S1413-70542008000600016.

RIZZON, L.A.; MIELE, A. Avaliação da cv. Cabernet Sauvignon para elaboração de vinho tinto. Ciência e Tecnologia de Alimentos, v.22, p.192-198, 2002. DOI: http://dx.doi.org/10.1590/ S0101-20612002000200015.

SANTOS, H.G. dos; JACOMINE, P.K.T.; ANJOS, L.H.C. dos; OLIVEIRA, V.A. de; LUMBRERAS, J.F.; COELHO, M.R.; ALMEIDA, J.A. de; CUNHA, T.J.F.; OLIVEIRA, J.B. de. Sistema brasileiro de classificação de solos. 3.ed. rev. e ampl. Brasília: Embrapa, 2013. 353p .

SOUZA, A.P. de; SILVA, A.C. da; LEONEL, S.; ESCOBEDO, J.F. Temperaturas basais e soma térmica para a figueira podada em diferentes épocas. Revista Brasileira de Fruticultura, v.31, p.314-322, 2009. DOI: https://doi.org/10.1590/S010029452009000200005.

SOZIM, M.; AYUB, R.A.; MALGARIM, M.B. Efeito do tipo de poda na produção e qualidade da videira cv. Vênus. Scientia
Agraria, v.8, p.169-172, 2007. DOI: https://doi.org/10.5380/rsa. v8i2.8382.

TECCHIO, M.A.; BOTELHO, R.V.; PIRES, E.J.P.; TERRA, M.M.; MAIA, J.D.G. Morfologia dos cachos e bagos de uvas 'Vênus' tratadas com quinmerac e ácido giberélico. Bioscience Journal, v.22, p.25-32, 2006.

TECCHIO, M.A.; MOURA, M.F.; TEIXEIRA, L.A.J.; PIRES, E.J.P.; LEONEL, S. Influence of rootstocks and pruning times on yield and on nutrient content and extraction in 'Niagara Rosada' grapevine. Pesquisa Agropecuária Brasileira, v.49, p.340-348, 2014. DOI: https://doi.org/10.1590/S0100-204X2014000500003.

TECCHIO, M.A.; TERRA, M.M.; MOURA, M.F.; PAIOLIPIRES, E.J. Fenologia e acúmulo de graus-dia da videira 'Niagara Rosada' cultivada ao noroeste do estado de São Paulo. Revista Brasileira de Fruticultura, v.33, p.248-254, 2011. Número especial. DOI: https://doi.org/10.1590/S0100-29452011000500030.

TSEGAY, D.; AMSALEM, D.; ALMEIDA, M.; CRANDLES, M. Responses of grapevine rootstocks to drought stress. International Journal of Plant Physiology and Biochemistry, v.6, p.1-6, 2014. DOI: https://doi.org/10.5897/IJPPB2013.0199.

WINKLER, A.J. Viticultura. México: Compañia Editorial Continental, 1965. 792p. 